\title{
Emotional Intelligence In Relation To Psychological Well-Being among Students
}

\author{
Dr. Sayeeda Shaheen ${ }^{1}$, Dr. Hameeda Shaheen ${ }^{2}$
}

\section{ABSTRACT}

The present study was aimed to investigate the emotional intelligence in relation to psychological well-being among students. The sample comprised 100 students (boys $=50$ \& girls =50), who were randomly selected from Senior Secondary Schools, AMU, Aligarh. The mean age of students was 15 years. Well-Being Manifestation Measure Scale (WBMMS; Masse, et al. 1998a) and Emotional Intelligence Scale (EIS; Schutte et al., 1998) was used to assess psychological well-being and emotional intelligence. Pearson Product-Moment Correlation and t-test were used to analyze the data. The results of the correlation showed that there is significant positive correlation between emotional intelligence and psychological well-being. Further, the result of the t-test showed that girls scored significantly higher as compare to boys on emotional intelligence, while there was no significant difference found between boys and girls scores on total psychological well-being and also on its any dimensions.

Keywords: Emotional intelligence, Psychological Well-being, Adolescents

It is difficult to describe best definition of psychological well-being, however the majority of previous researches define well-being as subjective satisfaction of one's life (Diener et al.,1999; Pavot \& Diener, 2003; Van Praag, Frijters, \& Ferrer-i-Carbonell, 2003) as according to Pavot and Diener (2003) well-being as the subjective feeling of contentment, happiness, satisfaction with life's experience and one's role in the world of work, sense of achievement, utility belongingness and no distress, dissatisfaction or worry etc. Similarly, in a study Salami (2010) defined psychological well-being is as a state that emerges from feeling of satisfaction with one's physical health and oneself as a person and with one's close interpersonal relationships.

\footnotetext{
${ }^{1}$ Ph.D., Department of Psychology, Aligarh Muslim University, Aligarh, India

${ }^{2}$ Post Doctoral Fellow (PDF;ICSSR), Department of Psychology, Aligarh Muslim University, Aligarh, India *Responding Author

(C) 2016, S Shaheen, H Shaheen; licensee IJIP. This is an Open Access Research distributed under the terms of the Creative Commons Attribution License (http://creativecommons.org/licenses/by/2.0), which permits unrestricted use, distribution, and reproduction in any Medium, provided the original work is properly cited.
} 


\section{Emotional Intelligence In Relation To Psychological Well-Being among Students}

\section{Emotional Intelligence}

The concept of emotional intelligence is emerged by Thorndike's (1920) theory of 'social intelligence' who defined social intelligence as - the ability to understand and manage men and women, boys and girls - to act wisely in human relations. Further, Gardner (1983) who gave the theory of multiple intelligences carried out the concept of social intelligence in the name of 'intrapersonal' and 'interpersonal' intelligence (an ability of understanding, motivating and managing the self) and then Sternberg (1988) in the name of contextual intelligence i.e. the ability to lead one's life successfully. Salovey and Mayer (1990a) put forward a theoretical model of social intelligence and viewed the emotional intelligence as a subset of social intelligence and define emotional intelligence as a type of social intelligence that involves the ability to monitor one's own and others emotions/feeling, to discriminate among them and to use the information to guide one's thinking and action (Salovey \& Mayer, 1990a; 1990b). Further, Mayer and Salovey (1997) have refined this definition in terms of four factors that is perceiving, using, understanding and managing emotions, as they define this "the ability to perceive accurately, appraise and express emotion; the ability to access and/or generate feelings when they facilitate thought; the ability to understand emotion and emotional knowledge; and the ability to regulate emotions to promote emotional and intellectual growth”. Goleman (1995) provided a broad and highly influential and vital importance of emotional intelligence in people's personal, social and professional lives. According to him intellectual intelligence contributes only $20 \%$ to one's success while the remaining $80 \%$ of a person's success in life is contributed by emotional and social intelligence (Goleman, 1995). Students with high emotional intelligence are prepared to deal with the challenges of new environment, setting up a responsibility schedule and study plan, meeting new people, and dealing with frustration and anxieties of being out of control of the environment (Goleman, 1998).

\section{Emotional Intelligence and Psychological Well-being}

Emotional intelligence play an important role in one's psychological wellbeing such as RuizAranda, Extremera, and Pineda-Galán (2014) studied on emotional intelligence, life satisfaction and subjective happiness in female student health professionals: the mediating effect of perceived stress in a 12-week follow-up study. They found that participants with higher emotional intelligence reported less perceived stress and higher levels of life satisfaction and happiness. Their results suggest that perceived stress mediates the relationship between emotional intelligence and well-being indicators, specifically life satisfaction and happiness. Further their findings suggest an underlying process by which high emotional intelligence may increase well-being in female students in nursing and allied health sciences by reducing the experience of stress. Mehmood and Gulzar (2014) assessed the connection of emotional intelligence with adolescent's psychological well-being (depression and self-esteem) and found significant positive relationship between variables of emotional intelligence and self-esteem and showed negative association between emotional intelligence and depression which indicate emotionally intelligent people adopt flexible patterns of life, which allow a person to adopt

(C) The International Journal of Indian Psychology, ISSN 2348-5396 (e)| ISSN: 2349-3429 (p) | 207 


\section{Emotional Intelligence In Relation To Psychological Well-Being among Students}

attitudinal changes, which protect a person to feel failure, neglected and development of depression. There is a stepwise structural chain between emotional intelligence and life success. High emotional intelligence facilitates or push the person toward getting positive sense of self, which contribute to developing high level of self-esteem. People who have high level of selfesteem are more open and assertive, and handle hardships more effectively and intelligently, which lead toward excellent performance and leading happy life. Cazan and Năstasă (2015) showed that emotional intelligence is related to better adjustment or success in academic settings. Also, high levels of emotional intelligence are associated with lower levels of anxiety, stress, and burnout and with higher levels of satisfaction with life.

\section{Objective:}

The following objectives are formulated for the present study:

1. To find out the relationship between emotional intelligence and psychological well-being among adolescents.

2. To find out the significant difference between male and female adolescents on emotional intelligence and psychological well-being.

\section{Hypotheses:}

The following hypotheses were formulated for the present study:

$\mathrm{H}-1$ : There will be positive correlation between emotional intelligence and psychological wellbeing among adolescents.

H-2: There will be significant difference between male and female adolescentson emotional intelligence and psychological well-being.

\section{METHODS}

\section{Participants}

For present study a sample of 100 adolescents (boys $=50 \&$ girls $=50$ ) were randomly assigned from both (boys and girls) Senior Secondary Schools of Aligarh Muslim University (AMU), Aligarh, India. The age of the participants was ranged between 16 to 19 years, and the average age was 15 years. All the participants came from middle socio-economic background.

\section{Instrument}

Well-Being Manifestation Measure Scale (WBMMS): Well-being manifestation measure scale was used for measuring psychological well-being which was developed by Masse, Poulin, Dassa, Lambert, Belair and Batttaglini (1998a). This scale consist 25-items with six factors or subscale that are control of self and events, happiness, social involvement, self-esteem, mental balance, and sociability. Masse, et al. (1998b), found an overall Cronbach's alpha of .93 for the questionnaire, and a range of .71 to .85 on the subscales. 


\section{Emotional Intelligence In Relation To Psychological Well-Being among Students}

Emotional Intelligence Scale (EIS): Schutte's Emotional Intelligence Scale (EIS: Schutte et al., 1998) was used for present study. The EIS consists of 33 self-referencing statements, for example, 'I know when to speak about my personal problems to others'. Participants are instructed to indicate the extent to which they agree or disagree with each statement using a 5point Likert scale. This scale ranged from 33 to 165, and high scores indicating as high EI of the person and vice-versa.

\section{Procedure}

For collecting the data investigator met the subjects in the classroom setting. After established a rapport and getting consent with the subject, the investigator administered three questionnaires i.e. demographic sheet, emotional intelligence, and psychological well-being. When all respondents were filled up their questionnaires, they were thanked by the investigator for their kind cooperation. Scoring of the responses was done according to the manual described for each questionnaire, and tabulation of the data was making carefully for its analysis. SPSS 16 was used for analysis of data.

\section{RESULT AND DISCUSSION}

The data were analysed by Descriptive statistics that is Mean, SD, and Pearson Product Moment Correlations were used to see the relationship of psychological variables of the total sample. $\mathrm{t}$ test were used for identifying gender differences of psychological variables i.e., emotional intelligence and psychological well-being. Results are presented in the following tables:

Table 1: Descriptive Statistics and Correlation between Emotional Intelligence and Psychological Well-Being of total students $(N=100)$.

\begin{tabular}{|c|c|c|c|c|c|c|c|c|c|}
\hline No. & Variables & 1. & i. & ii. & iii. & iv. & v. & vi. & 2. \\
\hline 1. & $\begin{array}{l}\text { Well-Being } \\
\text { Total }\end{array}$ & 1 & & & & & & & \\
\hline i. & Self-Esteem & $.675^{* *}$ & 1 & & & & & & \\
\hline ii. & $\begin{array}{l}\text { Mental } \\
\text { Balance }\end{array}$ & $.726^{* *}$ & $.373^{* *}$ & 1 & & & & & \\
\hline iii. & $\begin{array}{l}\text { Social } \\
\text { Involvement }\end{array}$ & $.570^{* *}$ & $.334^{* *}$ & $.257^{* *}$ & 1 & & & & \\
\hline iv. & Sociability & $.682^{* *}$ & $.431^{* *}$ & $.403^{* *}$ & .165 & 1 & & & \\
\hline v. & $\begin{array}{l}\text { Control of } \\
\text { Self and } \\
\text { Events }\end{array}$ & $.716^{* *}$ & $.293^{* *}$ & $.506^{* *}$ & $.414^{* *}$ & $.290^{* *}$ & 1 & & \\
\hline vi. & Happiness & $.748^{* *}$ & $.366^{* *}$ & $.406^{* *}$ & $.258^{* *}$ & $.549^{* *}$ & $.440^{* * *}$ & 1 & \\
\hline 2. & $\begin{array}{l}\text { Emotional } \\
\text { Intelligence }\end{array}$ & $.312^{* *}$ & $.303^{* *}$ & .178 & $.221^{*}$ & $.213^{*}$ & $.207^{*}$ & .179 & 1 \\
\hline & Mean & 89.97 & 13.95 & 14.81 & 14.62 & 14.78 & 13.21 & 18.60 & 113.30 \\
\hline & SD & 13.17 & 3.19 & 3.41 & 2.85 & 2.88 & 3.18 & 3.58 & 12.77 \\
\hline
\end{tabular}

Note. ${ }^{* *} \mathrm{p}<.01 ;{ }^{*} \mathrm{p}<.05$.

(c) The International Journal of Indian Psychology, ISSN 2348-5396 (e)| ISSN: 2349-3429 (p) | 209 


\section{Emotional Intelligence In Relation To Psychological Well-Being among Students}

Table- 1 shows that there is strong positive correlation between the psychological well-being total scores and emotional intelligence scores $(\mathrm{r}=.312 ; \mathrm{p}<.01)$. When we observe the psychological well-being dimensions scores with emotional intelligence scores then it was found that only four dimensions i.e. self-esteem ( $\mathrm{r}=.303 ; \mathrm{p}<.01)$, social involvement $(\mathrm{r}=.221 ; \mathrm{p}<.05)$,sociability $(\mathrm{r}=.213 ; \mathrm{p}<.05)$, and control of self and events $(\mathrm{r}=.207 ; \mathrm{p}<.05)$ are significantly positive correlated. Thus, the first hypothesis that there will be positive correlation between emotional intelligence and psychological well-being was confirmed as true. Result indicates that high levels of emotional intelligence are associated with higher levels of self-esteem, social involvement, sociability, control of self and events, and overall better psychological well-being of students life.

Table 2: Comparison of Girls $(N=50)$ and Boys $(N=50)$ Scores on Emotional Intelligence and Psychological Well-Being.

\begin{tabular}{|c|c|c|c|c|c|}
\hline No. & Variables & Gender & Mean & SD & t-value \\
\hline \multirow[t]{7}{*}{1.} & $\begin{array}{l}\text { Well-Being } \\
\text { Total }\end{array}$ & $\begin{array}{l}\text { Boys } \\
\text { Girls }\end{array}$ & $\begin{array}{l}89.86 \\
90.08\end{array}$ & $\begin{array}{l}13.63 \\
12.82\end{array}$ & -.083 \\
\hline & Self-Esteem & $\begin{array}{l}\text { Boys } \\
\text { Girls }\end{array}$ & $\begin{array}{l}13.70 \\
14.20\end{array}$ & $\begin{array}{l}3.27 \\
3.11\end{array}$ & -.783 \\
\hline & $\begin{array}{l}\text { Mental } \\
\text { Balance }\end{array}$ & $\begin{array}{l}\text { Boys } \\
\text { Girls }\end{array}$ & $\begin{array}{l}14.82 \\
14.80\end{array}$ & $\begin{array}{l}3.26 \\
3.59\end{array}$ & .029 \\
\hline & $\begin{array}{l}\text { Social } \\
\text { Involvement }\end{array}$ & $\begin{array}{l}\text { Boys } \\
\text { Girls }\end{array}$ & $\begin{array}{l}14.66 \\
14.58 \\
\end{array}$ & $\begin{array}{l}2.90 \\
2.83 \\
\end{array}$ & .140 \\
\hline & Sociability & $\begin{array}{l}\text { Boys } \\
\text { Girls }\end{array}$ & $\begin{array}{l}14.38 \\
15.18\end{array}$ & $\begin{array}{l}2.58 \\
3.12\end{array}$ & -1.397 \\
\hline & $\begin{array}{l}\text { Control of Self } \\
\text { and Events }\end{array}$ & $\begin{array}{l}\text { Boys } \\
\text { Girls }\end{array}$ & $\begin{array}{l}13.54 \\
12.88 \\
\end{array}$ & $\begin{array}{l}3.35 \\
2.99 \\
\end{array}$ & 1.038 \\
\hline & Happiness & $\begin{array}{l}\text { Boys } \\
\text { Girls }\end{array}$ & $\begin{array}{l}18.76 \\
18.44 \\
\end{array}$ & $\begin{array}{l}3.77 \\
3.41 \\
\end{array}$ & .445 \\
\hline 2. & $\begin{array}{l}\text { Emotional } \\
\text { Intelligence }\end{array}$ & $\begin{array}{l}\text { Boys } \\
\text { Girls }\end{array}$ & $\begin{array}{l}107.96 \\
118.64\end{array}$ & $\begin{array}{l}11.71 \\
11.58\end{array}$ & $-4.59 * *$ \\
\hline
\end{tabular}

Note. ${ }^{* *} p<.01$

Table-2 shows mean and SD of boys and girls on psychological well-being and emotional intelligence. The t-values in the table indicate that there is no significant difference was found between boys and girls on psychological well-being in total scores as well as in its any dimensions scores. When we observe emotional intelligence scores, it was found that girls' scored significantly higher $($ Mean $=118.64)$ as compare to boys' (Mean= 107.96; $\mathrm{p}<.01)$ on emotional intelligence scores. So our second hypothesis that there will be significant difference between male and female adolescents on emotional intelligence and psychological well-being was partially confirmed.

(C) The International Journal of Indian Psychology, ISSN 2348-5396 (e)| ISSN: 2349-3429 (p) | 210 


\section{Emotional Intelligence In Relation To Psychological Well-Being among Students}

Results of the present findings supported by previous studies that there is significant relationship exist between emotional intelligence and well-being among students (Kaur, 2015; Mehmood \& Gulzar, 2014). Further, present findings also indicate that there is no differences between boys and girls on psychological well-beings which was partially supported by the previous findings of Rathi and Rastogi (2007) who found no significant difference between males and females on other subscales of psychological well-being except self-esteem and mental balance. Inversely, the present findings was contradictory the findings of Akhter (2015) who found male and female students are differ in psychological well-being. Result also show that significant difference found on emotional intelligence which was supported previous findings (Naghavi \& Redzuan, 2011) who concluded that females have higher emotional intelligence than males and this may be reasoned by the individual differences and expectations of the society where girls are expected to be more emotionally expressive than males.

\section{CONCLUSION}

From the findings of the present study on emotional intelligence in relation to psychological well-being among students, it was concluded that there is significant positive relationship between emotional intelligence and psychological well-being. Further it was also concluded that there is gender difference on emotional intelligence as girls showed more emotional intelligence than boys.

Thus this study helps elucidate the role of emotional intelligence in students' mental balance, personal or social relationship, academic performance and in their overall psychological wellbeing. This study is significant implication for parents, teachers, and counsellors and future researchers for revealing how the development of emotional intelligence can lead to enhanced well-being of adolescents in society.

\section{Acknowledgments}

The author appreciates all those who participated in the study and helped to facilitate the research process.

\section{Conflict of Interests}

The author declared no conflict of interests.

\section{REFERENCES}

Akhter, S. (2015). Psychological well-being in student of gender difference. The International Journal of Indian Psychology, 2(4), 153-161.ISSN 2348-5396

Cazan, A. M., \& Năstasă, L. E. (2015). Emotional intelligence, satisfaction with life and burnout among university students. Procedia - Social and Behavioral Sciences, 180, 1574- 1578.

Diener, Ed., Suh, E., Lucas, R.E., \& Smith, H.L. (1999). Subjective well-being: Three decades of progress. Psychological Bulletin, 125(2), 276-302. 


\section{Emotional Intelligence In Relation To Psychological Well-Being among Students}

Gardner, H. (1983). Frames of mind: The theory of multiple intelligences. New York: Basic Books.

Goleman, D. (1995). Emotional intelligence: Why it can matter more than IQ. London: Bloomsbury.

Goleman, D. (1998). Working with emotional intelligence. New York: Bantam.

Kaur, J. (2015). Emotional intelligence enhances well-being. Indian Journal of Applied Research, 5(3), 562-564. ISSN - 2249-555X

Masse, R., Poulin, C., Dassa, C., Lambert, J., Belair, S., \& Batttaglini, A. (1998a). The structure of mental health higher-order confirmatory factor analyses of psychological distress and well-being measure. Social Indicators Research, 45, 475-504.

Masse, R., Poulin, C., Dassa, C., Lambert, J., Belair, S., \& Batttaglini, A. (1998b). Elaboration et validation d'un outil de mesure du bien-etrepsychologique: L'emmbep. Canadian Journal of Public Health, 89 (5), 352-357.

Mayer, J. D., \& Salovey, P. (1997). What is emotional intelligence? In P. Salovey\& D. J. Sluyter (Eds.), Emotional development and emotional intelligence: Educational implications (pp. 3-31). New York: Basic Books.

Mehmood, T. \& Gulzar, S. (2014). Relationship between emotional intelligence and psychological well-being among Pakistani adolescents. Asian Journal of Social Sciences \& Humanities, 3(3), 178-185.ISSN: 2186-8492

Naghavi, F. \& Redzuan, M. (2011). The relationship between gender and emotional intelligence. World Applied Sciences Journal, 15(4), 555-561.

Pavot, W., \& Diener, E. (2003). Well- being (inducing life satisfaction). In Rocio, FernadezBallesteror (Eds.) Encyclopedia of Psychological Assessment 2. New Delhi. Sage Publications, 1097-1101.

Rathi, N., \& Rastogi, R. (2007). Meaning in life and psychological well-being in pre-adolescents and adolescents. Journal of the Indian Academy of Applied Psychology, 33(1), 31-38.

Ruiz-Aranda, D., Extremera, N., \& Pineda-Galán, C. (2014). Emotional intelligence, life satisfaction and subjective happiness in female student health professionals: the mediating effect of perceived stress. Journal of Psychiatric and Mental Health Nursing,21 (2), 106-113. DOI: 10.1111/jpm.12052

Salami, S. O. (2010). Occupational stress and well-being: Emotional intelligence, self efficacy, coping, negative affectivity and social support as moderators. The Journal of International Social Research, 3(12), 387-398.

Salovey, P., \& Mayer J. D. (1990b) Concept of Emotional Intelligence. The Educational Review, 46(9). |

Salovey, P., \& Mayer, J. D. (1990a). Emotional intelligence. Imagination, Cognition, and Personality, 9, 185-211.

Schutte, N., Malouff, J., Hall, L., Haggerty, D., Cooper, J., Golden, C., \& Dorheim, L. (1998). Development and validation of a measure of emotional intelligence. Personality and Individual Differences, 25, 167-177. 


\section{Emotional Intelligence In Relation To Psychological Well-Being among Students}

Sternberg, R. J. (1988). Beyond IQ : A triarchic theory of human intelligence. Cambridge University Press. New York.

Thorndike, E. L. (1920). Intelligence and its uses. Harper's Magazine, 140, 227-235.

Van Praag, B. M. S., Frijters, P., \& Ferrer-i-Carbonell, A. (2003). The anatomy of subjective well-being. Journal of Economic Behaviour and Organization, 51(1), 29-49.

How to cite this article: S Shaheen, H Shaheen (2016), Emotional Intelligence In Relation To Psychological Well-Being among Students, International Journal of Indian Psychology, Volume 3, Issue 4, No. 63, ISSN 2348-5396 (e), ISSN: 2349-3429 (p), DIP: 18.01.115/20160304, ISBN: 978-1-365-32518-2 